seems from the figure to come very close to this species, especially in the form of the prothorax and the divided eyes. I might also add that fig. I I of the same plate (Cratoparis arcessitus,
No. 185) resembles somewhat Phloeosinus as does fig. 4, pl. Ix. (Exomias obdurefactus, No. roo5), except that in the latter the eyes are divided.

\title{
THE SPECIES OF HADROTETTIX, A GENUS OF OEDIPODINAE.
} BY SAMUEL H. SCUDDER, CAMBRIDGE, MASS.

Hadrotettix was established in 1876 , on a clumsy, strikingly banded Oedipodine with long and rather coarse antennae, from the Arkansas River, described by Say as Gryllus trifasciatus and figured in 1828 in his American Entomology. No species has since been added to the group,* although one from $\mathrm{Ne}$ braska has been catalogued by Bruner on several occasions. I have for some time had in my collection a Mexican species of very different appearance, so far as the markings of the wings go, and recently Mr. Morse has brought from California still another widely different species. Accordingly I append descriptions of the two additional species, leaving that named by Bruner to be described by him. The four species known to me may be separated by the following table : -

\section{Table of the species of Hadrotettix.}

$a^{1}$. Wings crossed by a broad fuscous band, as broad as the metazona, and following the hind border nearly to the anal angle; hind tibiae coral red.

\footnotetext{
*Thomas, however, twice described the original species under new names.
}

$b^{1}$. Band of wings with no taenia directed toward the base in the humeral field . . trifasciatus. $b^{2}$. Band of wings sending a humeral taenia at least one third the distance toward the base of the wings . . sracilis. $a^{2}$. Wings crossed by a narrow band not following the hind border toward the anal angle, or by a mere cloudy infuscation.

$b^{1}$. Nearly the whole apical half of tegmina membranaceous, the dense reticulation of the base extending but little beyond the middle; wings crossed by a distinct narrow fuscous band with a humeral taenia; hind tibiae greenish yellow . mundus. $b^{2}$. Only the apical fourth of tegmina membranaceous, the rest densely reticulated; wings merely obscured with fuscous clouds just beyond the middle and on the hind border; hind tibiae reddish yellow. . nebulosus.

\section{Hadrotettix trifasciatus.}

Gryllus trifasciatus Say, Amer. ent., iii., pl. 34 (1828).

Oedipoda trifasciata Walk., Cat. Derm. salt. Brit. Mus., iv, 729 (I870). 
Hadrotettix trifasciatus Scudd., Ann. rep. chief eng., r876, 51 I (1876). Arphia trifasciata Caulf., Rep. ent. soc. Ont., xviii, 70 ( 1888).

Oedipoda pruinosa Thom., Proc. acad. nat. sc. Philad., 187o, 8o (1870).

Oedipoda hoffmanii Thom., Rep. U. S. geol. surv. terr., v, I27 (1873).

I have specimens before me taken on the explorations for the N. Pacific R. R.; from the Upper Missouri and Yellowstone Rivers ; from south of the Black Hills, S. Dak., Nebraska City, Nebr., Colorado (Morrison), Pueblo, Col., Texas (Lincecum), Dallas, Tex. (Boll), Bosque Co., Tex. (Belfrage), Eagle Pass, Tex. (Schott), Pecos River, Tex. (Pope), and Fort Buchanan, Ariz. It has been reported from many of these districts by others, and also from Alaska [by error?] (Caulfield), Assiniboia (Scudder), British America (Bruner), Dakota and Montana (Bruner), Wyoming (Thomas, Bruner), Nevada (Thomas), Utah (Thomas, Saussure), Arkansas River (Say), and New Mexico (Scudder, Thomas, Saussure), so that it probably inhabits the whole Rocky Mt. region west of the eastern margin of the Great Plains, and east of the Sierras, from Assiniboia to the southern borders of 'Texas.

\section{Hadrotettix gracilis.}

Hadrotettix gracilis Brun.! MS., Publ. Nebr. acad. sc., iii, 25 (I893).

I have specimens from Valentine and Fort Robinson, Nelr., and Hot Springs, S. Dak., received from Bru- ner; as well as from Las Animas, Col., Bosque Co., Tex., and Fort Whipple, Ariz. It therefore has probably much the same range as the preceding. It is a little smaller than that species. I have also received this species from Bruner as coming from Nebraska and labelled H. minor Brun. MS.

\section{Hadrotettix mundus sp. nov.}

Moderately slender for the genus; brownish plumbeous, occasionally ferruginous, often and especially in the male more or less albescent, particularly on the hend; the latter well rounded, rather prominent, the fastigium of vertex slightly impressed, with a weak median carina, the frontal costa not very broad, expanded a little below the ocellus, a little sulcate and punctate, especially in the male; antennae scarcely $(\delta)$ or a little $(q)$ shorter than the hind femora, dull ferruginous, alternating obscurely with dull testaceous, often pallescent toward base. Pronotum of nearly uniform coloring, brownish plumbeous or ferruginous, but with the lateral lobes of ten more or less feebly albescent, particularly in the male, rarely obscurely punctate with fuscous, the lateral carinae prominent but rounded on the metazona, which is feebly rugulose and posteriorly rectangulate or subrectangulate. Tegmina brownish at base, beyond pale cinereous or albescent, crossed by two conspicuous heavy fuscous bands and a broken third band, often with a few obscure maculations apically, the dense reticulation of the base scarcely extending beyond the middle; wings pale citron yellow at base, crossed in the middle by a fuscous band scarcely if any wider than one of the bands of the tegmina, narrowed and interrupted at the lower margin of the humeral area, reaching the hind border but not following it toward the anal angle, sending a humeral taenia half way to the base, the wings beyond the band pellucid with infus- 
cated veins and a fuscous costal margin. Hind femora cinereous, banded in the middle of the apical half with fuscous, followed by a subflavous pregenicular band; hind tibiae pale greenish yellow, sometimes with a genicular fuscous maculation or cloud.

Length of body, $\delta, 25 \mathrm{~mm} .,+\%, 3 \mathrm{rmm}$; antennae, $\delta$, $12.5 \mathrm{~mm}$., $\&$, $14 \mathrm{~mm}$.; tegmina, $\delta, 25 \mathrm{~mm}$., $\&, 29.5 \mathrm{~mm}$.; hind femora,

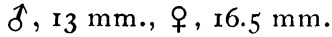

ı 6 , 16 9 . California, at Gazelle, Sept. 4-5, Tehama, Aug. 28, and Tulare, Aug. 5, A. P. Morse.

\section{Hadrotettix nebulosus sp. nov.}

Moderately stout; pale cinereous, more or less albescent. Head well rounded, not very prominent, the fastigium of vertex very obscure with no median carina, the frontal costa not very broad, feebly sulcate, punctate above; antennae a little shorter than the hind femora $(q)$, testaceous, infuscated in apical half by alternating bands of obscure fuscous. Pronotum brownish fuscous on metazona, pale cinereous on prozona, the lateral carinae bluntly rounded on metazona and hardly prominent; process of metazona rounded obtusangulate. Tegmina densely reticulated except the apical fourth, brownish fuscous at base, beyond dull cinereous, twice not very conspicuously banded with dull fuscous, with signs of a third band, and with obscure fuscous apical maculations; wings pellucid, fuliginous in a moderately broad band just beyond the middle, which is feeble in front, more marked behind, where it follows the hind border a short way toward the anal angle. Hind femora flavo-testaceous, twice banded interiorly with black or blackish fuscous, showing also above somewhat; hind tibiae pale reddish yellow, ringed at base with black and again obscurely in the middle of the basal half.

Length of body, $29 \mathrm{~mm}$; antennae, I3 mm.; tegmina, $27 \mathrm{~mm}$.; hind femora, 15.5 $\mathrm{mm}$.

2 ㅇ. Sinaloa, Mex., Koels (Behrens).

\section{LIFE HISTORIES OF NORTH AMERICAN GEOMETRIDAE. - XII.}

\section{BY HARRISON G. DYAR, WASHINGTON, D. C.}

Mecoceras nitocris Cram. The larva has not been previously described. Druce gives full references in the Biologia Cent.-Am., Lep. Het., ii, 94 .

Egg. Cylindrical, the ends rounded, one end a little more taperingly so than the other; a scarcely perceptible flattening of the cylinder, parallel to the leaf as laid. Twelve neat low ribs, reaching almost to the smaller end, becoming dotted at termination; stopping abruptly at the larger (micropylar) end in a circle of large, quadrangular, indistinctly edged cells, at the inner angles of which are a circle of white dots, one for each rib. Within this the micropyle is somewhat coarsely reticulate. Ribs thickly crested with a double alternating row of white dots. Cross-striafine, parallel, faint. Fine dark green; the ribs and circle of dots appear white. Size $.65 \times .55 \times .50 \mathrm{~mm}$.

Stage $I$. Head rounded, not bilobed, brown-black, not shining; width $.3 \mathrm{~mm}$. Body cylindrical, slender, feet normal ; central parts of segments bearing tubercles $i$ and ii larger, collared, 2-annulate, the interseg. mental parts smooth; ends shrunken. Dark vinous, almost blackish, the slender, intersegmental parts of joints 5 to 9 pale, sordid whitish with dorsal and subdorsal vinous lines, so that the body looks obscurely dark vinous banded. Tubercles small; setae black, stiff, iv behind the spiracle; on thorax ia to 

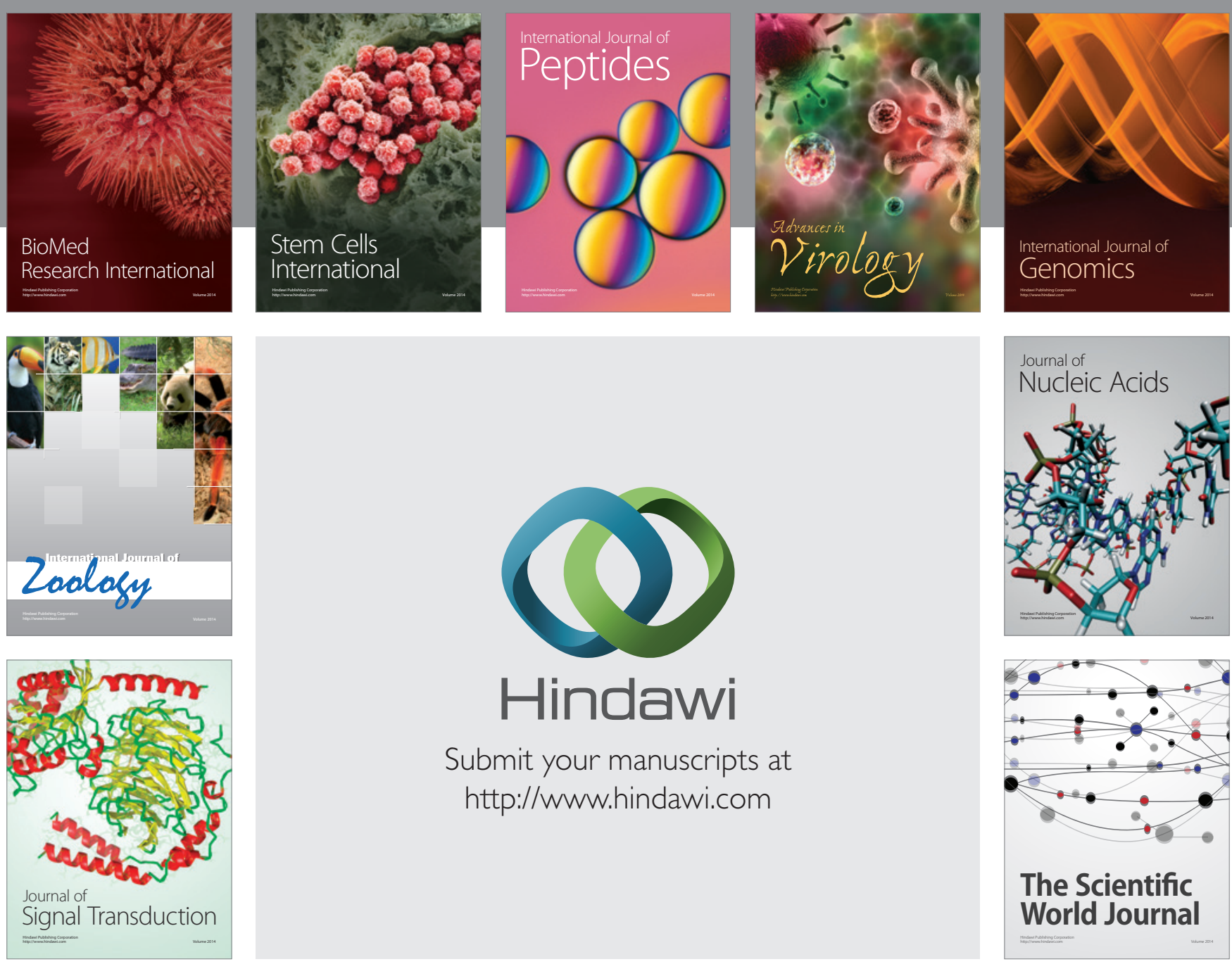

Submit your manuscripts at

http://www.hindawi.com
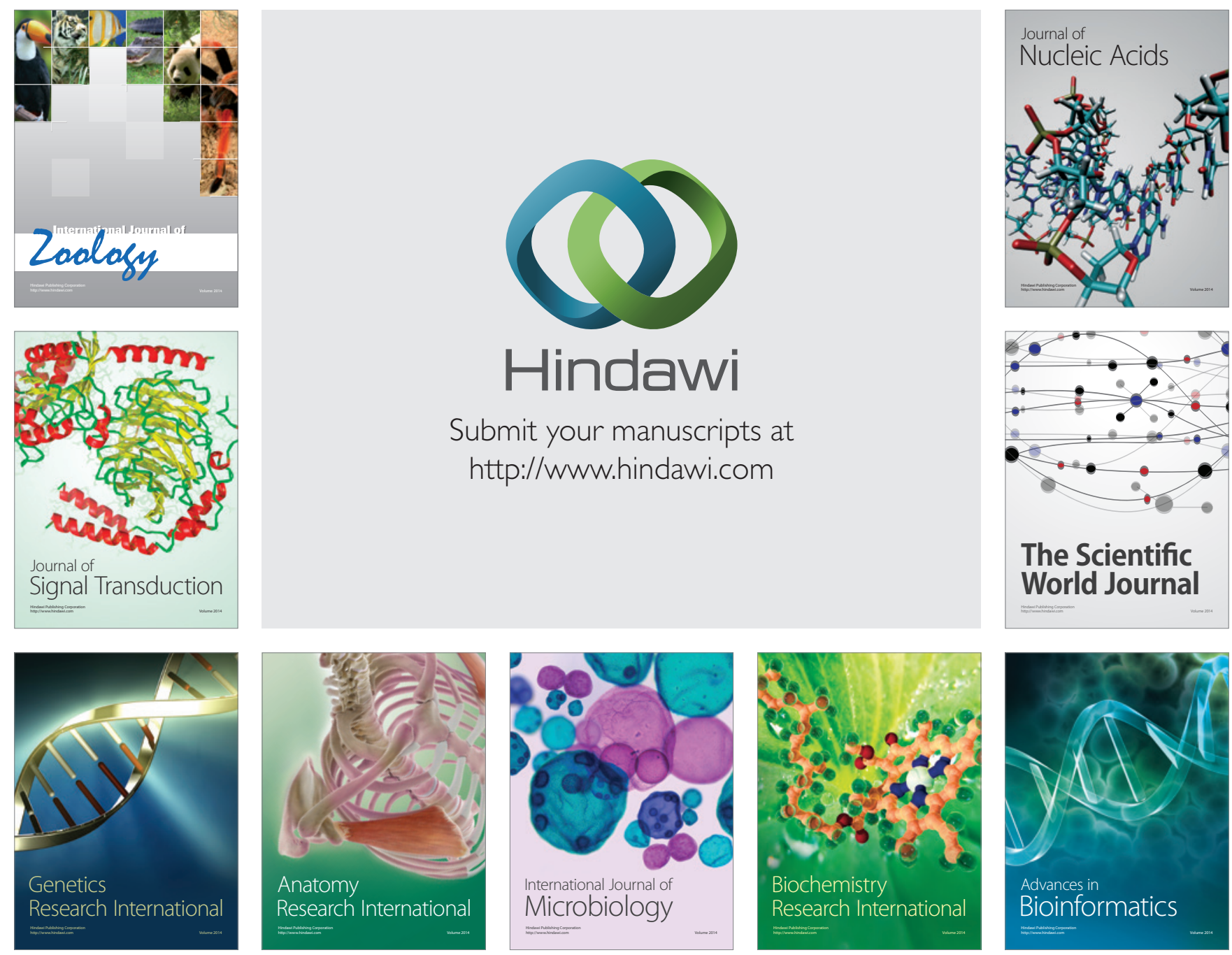

The Scientific World Journal
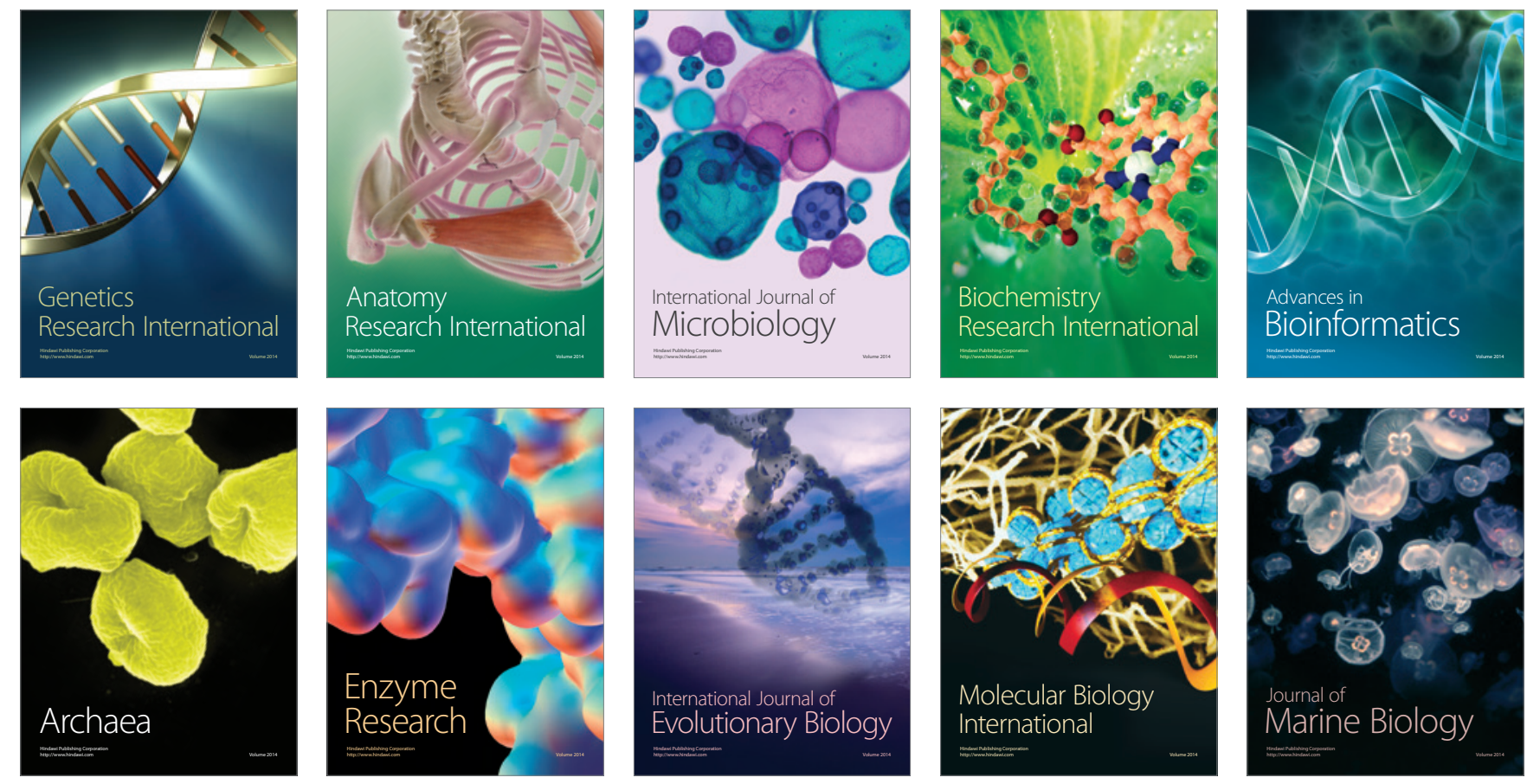